\title{
Causas internas y externas que determinan el rendimiento académico del estudiante universitario
}

Internal \& external causes determining the academic performance of the university student

Causas internas e externas que determinam o desempenho acadêmico do estudante universitário

José Andrés Alanís Navarro

Universidad Politécnica del Estado de Guerrero, México aalanis@upeg.edu.mx https://orcid.org/0000-0003-3337-2380

Reynaldo Alanís Cantú Universidad Politécnica del Estado de Guerrero, México ralanis2513@gmail.com http://orcid.org/0000-0001-5397-7016

Agustin Barón Universidad Nacional Autónoma de México, México agustinbaron@hotmail.com https://orcid.org/0000-0002-7307-5017 


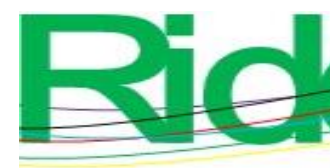

Revista Iberoamericana para la Investigación y el Desarrollo Educativo ISSN 2007 - 7467

\section{Resumen}

Este trabajo presenta un análisis de algunos factores asociados al fracaso de los estudiantes que estudian ingeniería. Una asignatura se considera fallida si la calificación final es menor a siete. La muestra estuvo compuesta por noventa y un estudiantes que se encuentran en el séptimo semestre de Ingeniería en Energía, Ingeniería en Tecnología Ambiental e Ingeniería en Telemática. La muestra representa el 59,9\% de la población. Los datos fueron recolectados a través de un instrumento de 24 preguntas. La edad de los alumnos oscila entre 20 y 36 años. Como posibles factores internos, que están directamente asociados con el estudiante, se incluyen: el tiempo adicional que el estudiante dedica al estudio, la elección de la carrera deseada o el tiempo dedicado a otras actividades personales, entre otros factores. Como posibles factores externos se analizan el estado socioeconómico del ingreso familiar, la calidad de la enseñanza, la calidad de la infraestructura de la universidad, entre otros factores. Se realiza un análisis de las estadísticas descriptivas de cada factor y se presenta un resumen de la información relevante. Del mismo modo, se determina el grado y el tipo de correlación entre cada factor y el número de sujetos fallidos por alumno. Además, se presentan los factores asociados a la satisfacción profesional del alumno. Las variables Edad, Miembros de familia, Tiempo de trabajo, Ingresos mensuales, Gasto diario y Consumo de drogas no presentan ningún tipo de correlación con la variable de interés. El desempeño de los estudiantes se relaciona principalmente con factores internos, aspectos que sólo dependen del estudiante; sólo el factor externo de relación del alumno está asociado a su desempeño. Por otro lado, el sentimiento de satisfacción del estudiante por la carrera estudiada depende principalmente de factores externos como el apoyo familiar, la calidad de la enseñanza, la relación entre docentes y alumnos y la calidad de la infraestructura; el único factor interno es el auto-concepto de la comprensión. Con esta información se pretende plantear propuestas concretas para evitar o disminuir la deserción escolar, además de aminorar los posibles efectos sociales que este fenómeno puede provocar a corto o mediano plazo.

Palabras clave: rendimiento escolar, auto-concepto de comprensión, coeficiente de correlación lineal, coeficiente de Pearson, coeficiente de Spearman. 


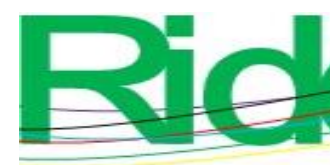

Revista Iberoamericana para la Investigación y el Desarrollo Educativo ISSN $2007-7467$

\section{Abstract}

This work presents an analysis of some factors associated with the failure of students who are studying engineering. A subject is considered failed if the final grade is less than seven. The sample was composed of ninety-one students who are in the 7th semester of Energy Engineering, Environmental Technology Engineering and Telematics Engineering. The sample represents $59,9 \%$ of the population. The data were collected through a 24-question instrument. The age of the students ranges between 20 and 36 years. As possible internal factors, which are directly associated with the student, include: the extra time the student dedicates to study, the choice of desired career, or the time dedicated to other personal activities, among other factors. As possible external factors are analyzed the socioeconomic status of the family income, the quality of teaching, the quality of infrastructure of the university, among other factors. An analysis of descriptive statistics of each factor is carried out and a summary of the relevant information is presented. Likewise, the degree and type of correlation between each factor and the number of failed subjects per student is determined. In addition, the factors associated with the student's career satisfaction are presented. The variables Age, Family members, Work time, Monthly income, Daily spending, and Drug consumption, does not present any type of correlation with the variable of interest. The students' performance is mainly related to internal factors that are aspects that only depend on the student himself; only the external factor Student's relation is associated with its performance. On the other hand, the feeling of satisfaction of the student for the studied career depends mainly on external factors such as Family support, Teaching quality, Teacher and Student relation, and Infrastructure quality; the only internal factor is the self-concept of comprehension. This information is intended to make concrete proposals to prevent or reduce school drop-out, as well as to lessen the possible negative social effects that this phenomenon may cause in the short or medium term.

Keywords: Scholar performance, self-concept of comprehension, linear correlation coefficient, Pearson coefficient, Spearman coefficient. 


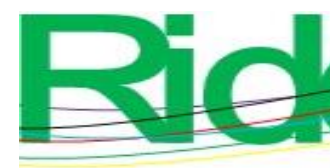

Revista Iberoamericana para la Investigación y el Desarrollo Educativo ISSN $2007-7467$

\section{Resumo}

Este trabalho apresenta uma análise de alguns fatores associados ao insucesso de alunos do curso de engenharia. Um curso é considerado reprovado se a nota final for inferior a sete. A amostra foi composta por noventa e um alunos que cursam o sétimo semestre de Engenharia em Energia, Engenharia em Tecnologia Ambiental e Engenharia em Telemática. A amostra representa 59,9\% da população. Os dados foram coletados por meio de um instrumento de 24 questões. A idade dos alunos varia entre 20 e 36 anos. Os possíveis fatores internos, que estão diretamente associados ao aluno, incluem: o tempo adicional que o aluno dedica aos estudos, a escolha da carreira desejada ou o tempo dedicado a outras atividades pessoais, entre outros fatores. Como possíveis fatores externos, são analisados o nível socioeconômico da renda familiar, a qualidade do ensino, a qualidade da infraestrutura universitária, entre outros. É realizada uma análise da estatística descritiva de cada fator e apresentado um resumo das informações relevantes. Da mesma forma, o grau e o tipo de correlação entre cada fator e o número de matérias reprovadas por aluno são determinados. Além disso, são apresentados os fatores associados à satisfação profissional do aluno. As variáveis Idade, Familiares, Tempo de trabalho, Renda mensal, Despesa diária e Uso de medicamentos não apresentam nenhum tipo de correlação com a variável de interesse. $\mathrm{O}$ desempenho do aluno está relacionado principalmente a fatores internos, aspectos que dependem apenas do aluno; apenas o fator externo da relação do aluno está associado ao seu desempenho. Por outro lado, o sentimento de satisfação do aluno com o diploma estudado depende principalmente de fatores externos como o apoio familiar, a qualidade do ensino, a relação entre professores e alunos e a qualidade da infraestrutura; o único fator interno é o autoconceito de compreensão. Essas informações têm como objetivo fazer propostas concretas para evitar ou reduzir o abandono escolar, além de reduzir os possíveis efeitos sociais que esse fenômeno pode causar a curto ou médio prazo.

Palavras-chave: desempenho escolar, conceito de autocompreensão, coeficiente de correlação linear, coeficiente de Pearson, coeficiente de Spearman.

Fecha Recepción: Septeimbre 2019

Fecha Aceptación: Junio 2020 


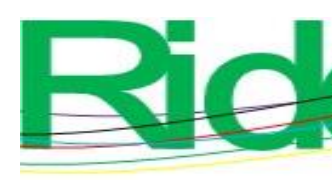

Revista Iberoamericana para la Investigación y el Desarrollo Educativo ISSN 2007 - 7467

\section{Introduction}

Students from different universities have problems with their grades, for this reason, it is necessary to implement Surveys of Academic Orientation (SAO), and it is also recommended do it from the first year of the high school level. Universities would benefit from an early warning system that detects students at risk before the performance or social problems jeopardize their university career (Beck \& Davidson, 2001). There are personal factors that influence the academic performance of students, which in this work are called internal factors: factors that are attributed solely to the student. Likewise, there are external factors, which are external for the student, which can have a significant impact on their academic performance. Although at the same time evaluating the SAO score, attention needs to be paid to other academic indices such as student stress (Beck \& Davidson, 2001). Studies have been carried out to analyze the influence of the time that students invest in studying and working. In this study, it was concluded that there is no relation between these two factors and the academic performance of students (Nonis \& Hudson, 2010). It was also analyzed how career satisfaction and academic performance are related, observing that study satisfaction is linked to non-cognitive factors such as motivation and the organization of academic courses, while academic development is influenced by factors, cognitive factors such as the final grade of the school and the students' learning behavior. Likewise, successful and/or satisfied students are more motivated to supplement their course of study for a regular period and then be employed as social workers (Blanz, 2013). In addition to internal factors, the influence of external factors on academic performance has been studied. Some studied factors are social and economic pressure, the family situation, difficulties in the discipline, the demands of teachers and pedagogical difficulties (Roman, 2013). In other studies, a relation has been observed between the qualification of the students and their personal life. Teachers pass students as competent when there is evidence to the contrary; because some academics let themselves be influenced by the personal and problematic life of the students (Finch \& Taylor, 2014).

The relation between learning styles and academic performance has also been analyzed; the academic performance of the students was measured using their general grade point average. The study was done using two types of questionnaires, one of which was the learning style inventory and the environmental productivity preference survey. In their study, they emphasize that the academic performance of the students is related to the way in which they learn (Torres, 2014). On the other hand, the classroom is a fundamental aspect of the students' learning since it 


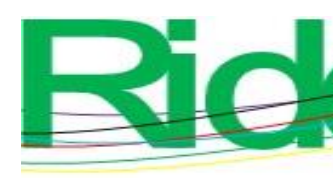

Revista Iberoamericana para la Investigación y el Desarrollo Educativo ISSN $2007-7467$

transmits the educational philosophy. The design of the classroom has not changed since the medieval era, the only change has been its size (Park \& Choi, 2014). An attempt to develop a different perspective of the educational environment, a new classroom design has been implemented: the active learning classroom (ALC) was established at SoongSil University Korea. Two surveys were carried out to evaluate the learning of the students in the ALC and the results were compared with the traditional classroom. The result was that in the traditional classroom there are two zones: one of "gold" and one zone of "shadow", which discriminates the learning experience of each student (Park \& Choi, 2014). In the ALC, no such positional discrimination occurred. The students perceived the most inspiring active learning classroom environment, especially regarding active participation in classes. Students with more emphasis on academic achievement showed a better tendency to share information and create new ideas in the ALC. In the traditional classroom, only students with a high-grade point average were more motivated to learn (Park \& Choi, 2014). Identifying the predictors of academic performance is crucial for post-secondary institutions, as this allows them to select the students with the greatest chance of success. In previous studies, they showed that high school students with a higher average grade level, or lower grade on standardized tests, are associated with greater preparation for college (Komarraju, Ramsey, \& Rinella, 2012). Another study is based on students' intention of achievement that is, self-efficacy and self-concept, registered as internal factors, in which they found a direct relation between these two factors regarding academic performance, social acceptance and labor competency (Fenning \& May, 2013). However, there are also studies in which the teacher is attributed most of the responsibility for the academic performance of the students and their final grades; that is, to external factors to the student. They have concluded that the teacher does not usually motivate the student or worry about those who are in a failure situation (Herrera, 2016).

\section{Materials \& methods}

In order to carry out this study, students of the 7th semester of the engineering careers of a university were chosen. The population of interest is the students of Energy Engineering, Environmental Technology Engineering, and Telematics Engineering, where a high failure rate has been observed. The age of the students ranges between 20 and 36 years. To determine the factors of students' disapproval, a survey of 24 questions is implemented, with which information 


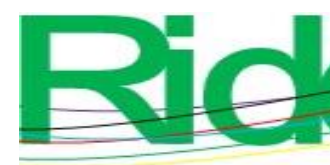

Revista Iberoamericana para la Investigación y el Desarrollo Educativo ISSN $2007-7467$

is obtained of the student's academic history, the personal activities they make, as well as the perception they have about their own university, teachers, and fellow students, see the complete survey in Appendix A. Starting from the fact that the population is known or finite, $\mathrm{N}=152$, it is possible to determine the size of the sample, $n$, necessary to perform the study with a certain degree of uncertainty. To do this, the statistical sampling technique for finite populations is used (Martínez, 2008). The conditions used for the sample selection are the following: i) finite population, ii) a confidence level of $99 \%$, this implies a value $\mathrm{Z}_{99 \%}=2,58$; y, iii) an accuracy or allowed error of the $10 \%$, i.e., e $=0,10$. Under these considerations, the sample size is 80 participants. The way to calculate the sample size for finite populations is presented in detail in the reference (Alanís, Casarrubias, Cantú, \& Lavín, 2017). The collected information is organized and statistically analyzed, this consists of obtaining the main measures of location or central tendency, as well as measures of dispersion or variability (Devore, 2008). Additionally, a histogram is obtained from each factor analyzed and compared to a normal distribution curve, in order to understand its degree of skewness and kurtosis, that is, its degree of asymmetry and its form, respectively (Spiegel \& Stephens, 2009). The degree and type of correlation that exists between the accumulated numbers of failed subjects are calculated, with respect to each factor collected in the survey.

The degree and type of correlation are obtained by calculating Pearson's linear correlation coefficient (Pearson, 1920) and Spearman (Spearman, 1904). By means of the value of both coefficients it is possible to discern whether the analyzed data set presents atypical or deviated data (Alanís, Casarrubias, Cantú, \& Lavín, 2017); that is, if both parameters are similar, the presence of atypical data is discarded. For this reason, not only are both coefficients calculated, but the difference between them is determined, furthermore to calculating and presenting the average of both coefficients, which is determined as $r=0,5\left(r_{p}+r_{s}\right)$.

\section{Results \& discussion}

\section{Statistical analysis}

The parameters obtained by means of the statistical analysis were the measurements of location or central tendency; the measures of dispersion or variability, as well as the measures of form and pointing. In the central tendency measurement, the mean, the median, and the mode were calculated. To represent the variability of the data, the minimum and maximum values, the 


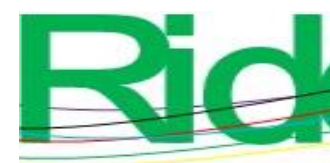

Revista Iberoamericana para la Investigación y el Desarrollo Educativo ISSN $2007-7467$

standard deviation, the variance and the coefficient of variation. The asymmetry coefficient and kurtosis were determined for the shape and pointing measurements, respectively. In Table 1, the descriptive statistical analysis is presented. The complete nomenclature is presented in Appendix B.

Table 1. Descriptive statistics summary

\begin{tabular}{|c|c|c|c|c|c|c|c|c|c|c|}
\hline Factor & $\bar{x}$ & $\tilde{x}$ & $\widehat{\boldsymbol{x}}$ & $\mathbf{X} \min$ & $\mathbf{X}_{\max }$ & $\mathbf{S}$ & $\mathbf{s}^{2}$ & $\mathbf{C V}$ & $\mathbf{S k}$ & $\mathbf{k}$ \\
\hline Age & 22 & 21 & 21 & 20 & 36 & 2,4 & 5,9 & 0,11 & 3,2 & 13,8 \\
\hline Family members & 5 & 5 & 4 & 2 & 10 & 1,6 & 2,6 & 0,33 & 0,5 & 0,2 \\
\hline Work time & 8,8 & 1,3 & 0,0 & 0,0 & 48,0 & 12,7 & 162,0 & 1,45 & 1,5 & 1,0 \\
\hline Monthly income & 8,8 & 6,0 & 5,0 & 3,5 & 40,0 & 7,0 & 49,6 & 0,80 & 2,7 & 8,3 \\
\hline Middle school average & 8,4 & 8,2 & 8,0 & 7,0 & 9,9 & 0,7 & 0,4 & 0,08 & 0,2 & $-0,3$ \\
\hline Failed at middle school & 2 & 2,0 & 2,0 & 0,0 & 2,0 & 0,6 & 0,3 & 0,38 & $-0,6$ & $-0,7$ \\
\hline Failed at high school & 2 & 1,0 & 0,0 & 0,0 & 13,0 & 2,4 & 5,6 & 1,33 & 1,9 & 4,9 \\
\hline Transport time & 0,8 & 0,8 & 1,0 & 0,1 & 2,5 & 0,5 & 0,3 & 0,60 & 1,1 & 0,8 \\
\hline Daily spending & 79 & 70 & 70 & 35 & 170 & 25,3 & 639,4 & 0,32 & 1,2 & 2,0 \\
\hline Extra study time & 2 & 2 & 2 & 0 & 5,0 & 1,0 & 1,1 & 0,58 & 0,7 & 0,3 \\
\hline Distraction time & 8 & 5 & 2 & 0 & 50 & 10,3 & 106,2 & 1,24 & 3,0 & 9,5 \\
\hline Use of devices & 4 & 4 & 4 & 1 & 8 & 1,5 & 2,1 & 0,36 & 0,4 & 0,1 \\
\hline Device usage time & 4 & 3 & 2 & 1 & 40 & 5,0 & 25,2 & 1,12 & 4,6 & 28,7 \\
\hline Drug consumption & 1 & 0 & 0 & 0 & 4 & 1,0 & 0,9 & 1,33 & 1,4 & 1,9 \\
\hline Desired career & 8 & 8 & 8 & 1 & 10 & 1,7 & 2,9 & 0,21 & $-1,4$ & 3,0 \\
\hline Career satisfaction & 8 & 9 & 9 & 1 & 10 & 1,8 & 3,3 & 0,22 & $-2,0$ & 4,9 \\
\hline Family support & 9 & 10 & 10 & 2 & 10 & 1,9 & 3,6 & 0,22 & $-1,8$ & 3,1 \\
\hline Classes understanding & 7 & 8 & 8 & 1 & 10 & 1,9 & 3,6 & 0,25 & $-1,3$ & 1,5 \\
\hline Teaching quality & 8 & 8 & 8 & 2 & 10 & 1,5 & 2,1 & 0,18 & $-1,8$ & 4,8 \\
\hline Teacher relation & 8 & 8 & 8 & 1 & 10 & 1,6 & 2,7 & 0,20 & $-1,8$ & 4,8 \\
\hline Students relation & 8 & 8 & 8 & 2 & 10 & 1,8 & 3,2 & 0,23 & $-1,2$ & 1,3 \\
\hline Infrastructure quality & 7 & 7 & 7 & 1 & 10 & 1,9 & 3,7 & 0,27 & $-1,3$ & 1,9 \\
\hline Family troubles & 5 & 4 & 1 & 1 & 10 & 3,2 & 9,9 & 0,68 & 0,3 & $-1,4$ \\
\hline Health conditions & 8 & 9 & 10 & 1 & 10 & 1,8 & 3,1 & 0,21 & $-1,9$ & 4,5 \\
\hline
\end{tabular}

Source: own elaboration 

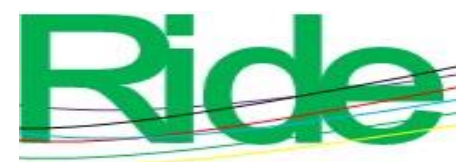

Revista Iberoamericana para la Investigación y el Desarrollo Educativo

The factors that exhibit a greater variability are I3, I7, E2, I11, and I13, which present a coefficient of variation of $1,45,1,33,1,24,1,12$ and 1,33, respectively. On the other hand, the factors that have less variability are: I1, I6, I13, E5, E6, and I15, having a coefficient of variation of $0,11,0,08,0,21,0,18,0,20$ and 0,21 , respectively. According to the factors evaluated in the discrete quantitative scale: 1-10, its average is shown in Figure 1.

Figure 1. Average of some internal and external factors

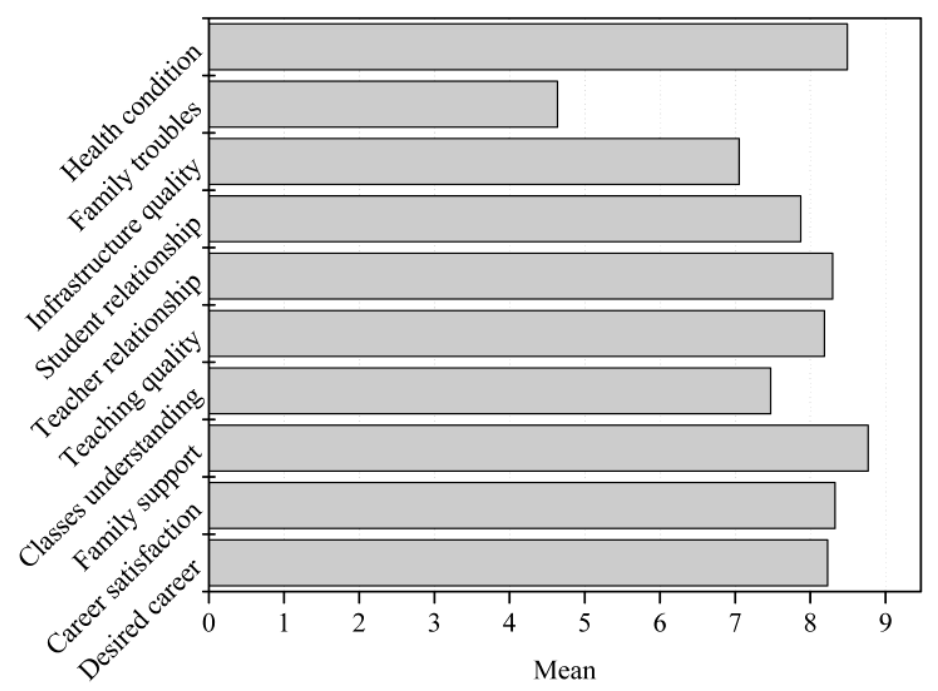

Source: own elaboration

This section presents the main results based on the most frequent answers. The interval class or mode of the internal and external factors is shown. In relation to internal factors, 63,7\% of students are between 20 and 22 years old; 46,2\% of their families are made up of between four and six members. In addition, of the students that realize some kinds of work to pay for their studies, 56,7\% work less than five hours per week, but 49,5\% of the students do not work. Even though the monthly family income of the students has significant variability, 52,7\% registered to have a monthly family income between five thousand and 10 thousand Mexican pesos. Regarding the academic performance of the students prior to the university, 30,7\% of the students finished the upper-middle level with an average (in the scale of 0 to 10) between 8,0 and 8,5, and 53,8\% mentioned having failed two subjects; $56,0 \%$ of the students have failed one to two subjects during the six previous periods that they have studied in their university; $35,1 \%$ spends on average $\$ 70$ daily; it should be noted that the average minimum wage in this area is $\$ 83$. Only $31,8 \%$ of students studied between $2,0 \mathrm{~h}$ to $2,5 \mathrm{~h}$ per week outside class time. Regarding the purchasing capacity of students and their families, 30,8\% of the scholars mentioned having five 


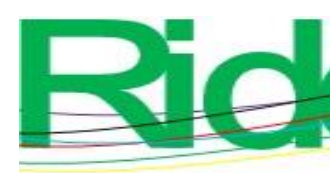

Revista Iberoamericana para la Investigación y el Desarrollo Educativo ISSN $2007-7467$

electronic entertainment devices in their home and, 71,4\% use them up to five hours each week; above $53,3 \%$ of the students mentioned frequently consume some kind of drug. About one-third of the students, i.e., 29,7\%, mentioned being $80 \%$ sure of having chosen the correct career. In relation to the self-concept of the students, only 35 (35,8\%) of them consider understanding $80 \%$ of the classes of different subjects. On the other hand, 40,6\% rated their health status as completely healthy.

Regarding external factors, it was observed that the transport time students spend to get to the university, 32,9\% travels between $24 \mathrm{~min}$ and $36 \mathrm{~min}$; a higher percentage: 40,4\%, uses five hours - as a maximum - for personal entertainment, this includes spending time with their partners or friends. Besides, 31,9\% considers being 90\% satisfied with the career of their choice; $57,1 \%$ of student consider having the full support of their families for the completion of their studies. About the quality of education, $41,1 \%$, that is 37 students consider that teaching is $80 \%$ of good quality. To say the academic relation between teachers and students, 30 students; this is $40,6 \%$, consider that it is $80 \%$ good; However, only $27,5 \%$ think that the relationship with their classmates is of the same quality as their teachers. Concerning about the institution infrastructure's quality, near a third of the students $(31,9 \%)$ rated it as good in order of $70 \%$. Finally, 26,4\% of students mentioned having no family troubles.

\section{Correlation with factor I7: Failed at high school}

This analysis consisted in determining the degree and type of linear correlation of all the analyzed factors respect to the factor I7: Failed at high school, through the calculation of the coefficient of Pearson correlation, $r_{p}$, and Spearman, $r_{s}$. The combination of the possible relations between all the analyzed factors is 276 . Even though both correlation coefficients have the same purpose, for comparative purposes it is convenient to calculate both coefficients, because the Spearman coefficient is robust to the presence of scattered data (Zou, Tuncali, \& Silverman, 2003). As a preliminary analysis and in order to determine their similarity between both correlation coefficients, the difference between the two coefficients was calculated, which is expressed as the absolute value. From this analysis, it was obtained that $48,6 \%$ of the data does not present any difference, while $34,4 \%$ of the analyzed factors present a difference of one-tenth or less. On the other hand, $15,6 \%$ of the factors show a variation of only two tenths. Approximately 1,4\% of the data have a difference between both coefficients for the same pair of factors of 0,3 ; finally, only a couple of factors presented a difference of 0,4 , which represents $0,4 \%$ of the data. Table 2 

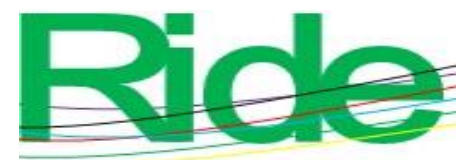

Revista Iberoamericana para la Investigación y el Desarrollo Educativo

ISSN $2007-7467$

shows the average of both linear correlation coefficients, both internal and external factors. $83,7 \%$ of the data, i.e., 231 , have a very weak relation, while $12,0 \%$ of the data, i.e., 33, presents weak degree of correlation with the variable of interest, I7. However, there are another factors that correlate moderately since they have a correlation coefficient between 0,4 and 0,65 , this is the case of $4,3 \%$ of the data, that is 12 pairs of analyzed factors. The complete nomenclature of the factors is presented in Appendix C.

According to the factor of interest I7 correlation respect to the rest of factors, neither internal nor external, a weak or poor grade correlation was obtained respect to i) Middle school average (I5), ii) Failed at middle school (I6), iii) Extra study time (I9), iv) Use of devices (I10), and v) Classes understanding (I14), the correlation grade is: $-0,35,-0,27,-0,30,0,21$, and $-0,22$, respectively, see Figure 2. In Figure 3, the histogram of the I7 factor is presented. As descriptive proposes, some histograms of factors presenting the highest correlation respect to I7 are depicted. These factors are the Middle school average (I5), and Classes understanding (I14), see Figures 4 and 5, respectively. The factor I6: Failed at middle school, shows that 96,7\% of students failed at least two courses; in other words, only three students didn't fail any courses at middle school.

Figure 2. Pearson and Spearman average coefficient of weak correlated factors to I7.

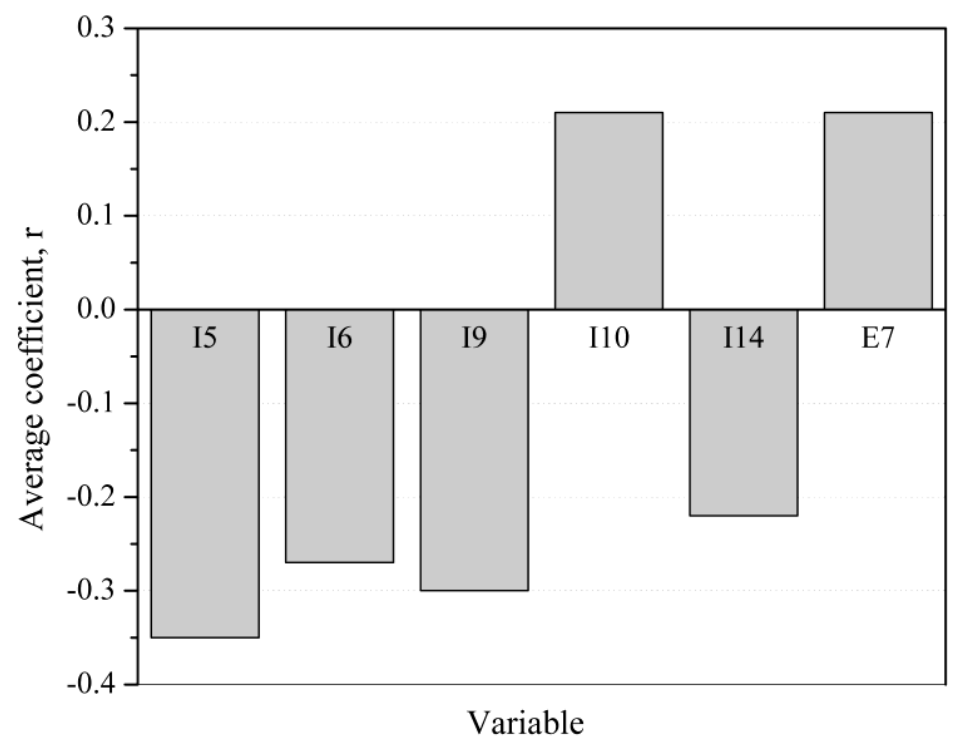

Source: own elaboration. 
Figure 3. Histogram of Failed at high school factor.

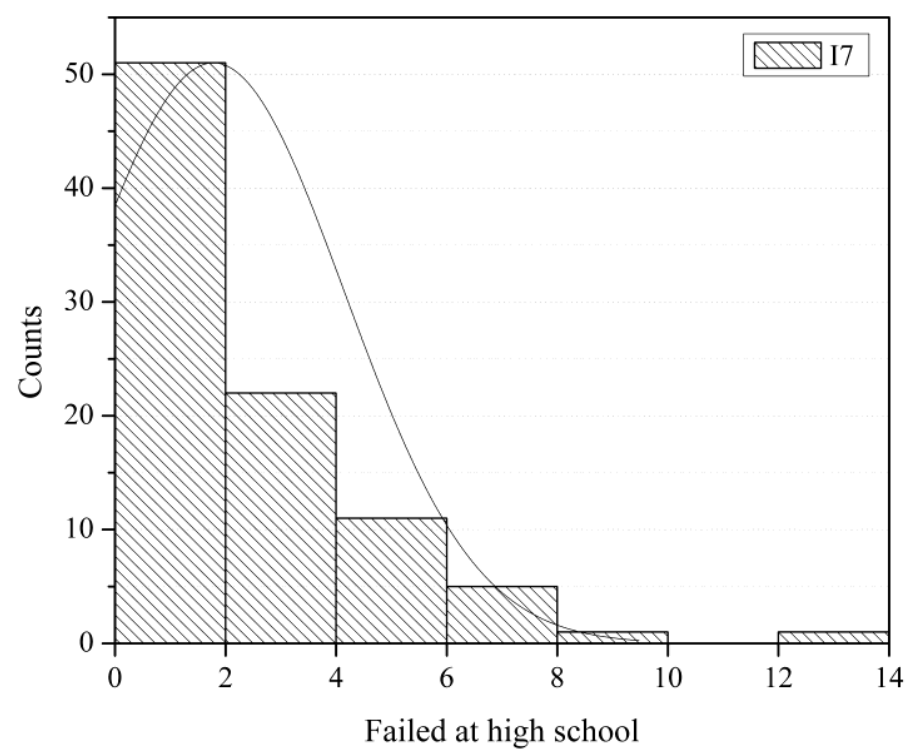

Source: own elaboration

Figure 4. Histogram of Middle school average factor.

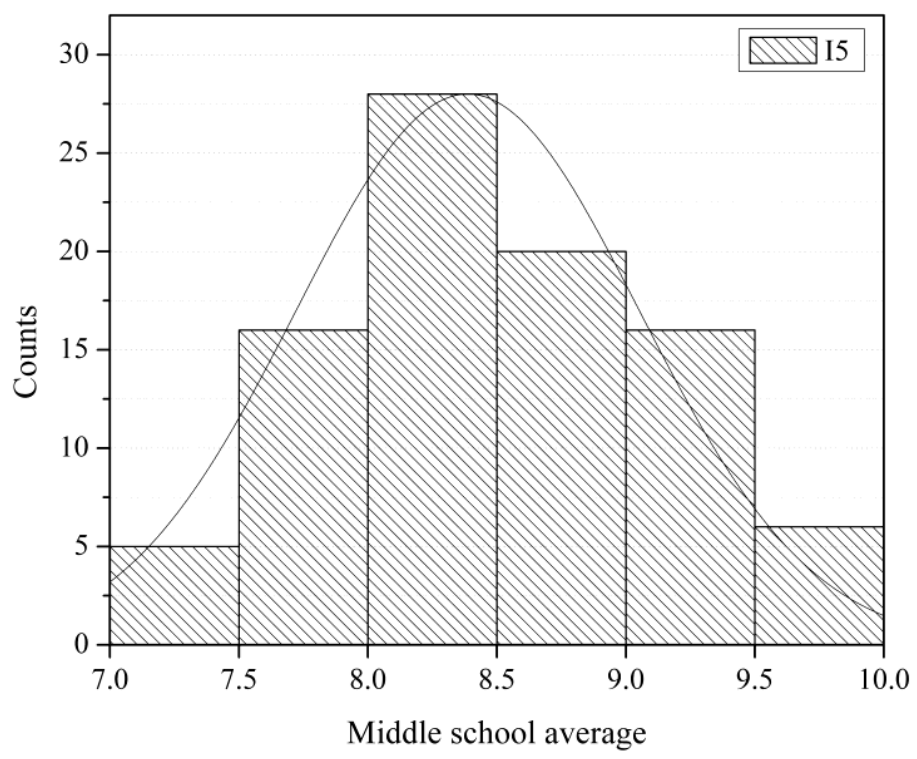

Source: own elaboration. 
Figure 5. Histogram of Classes understanding factor.

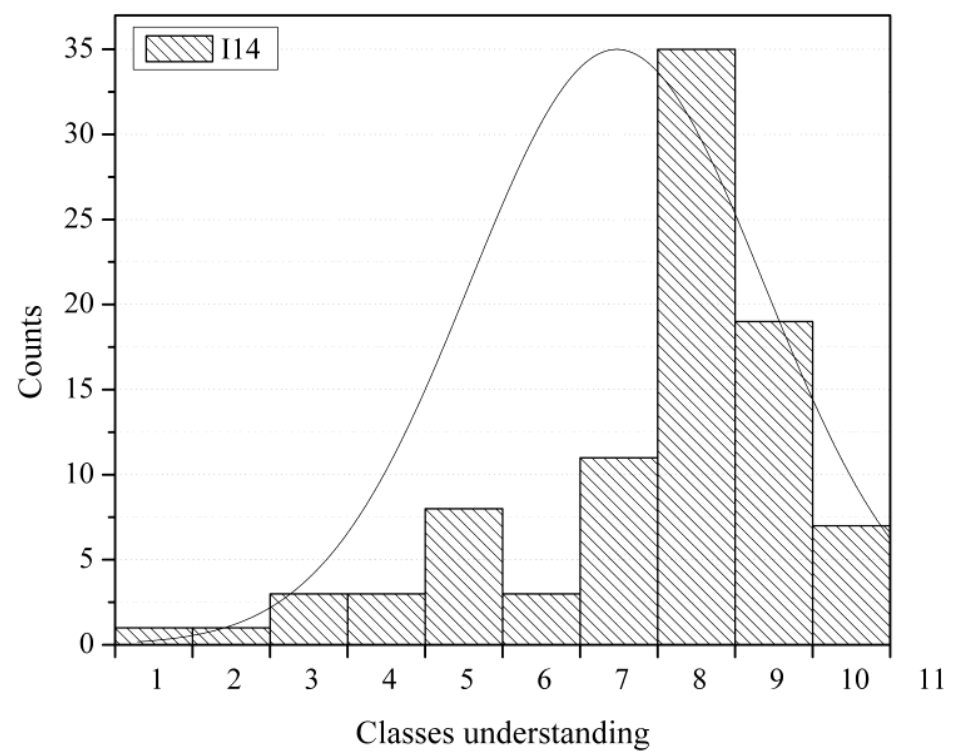

Source: own elaboration

\section{Other correlations}

The degree and type of correlation between each pair of factors were determined by calculating the average of the Pearson and Spearman coefficients. A moderate positive correlation of 0,49 was observed in the perception of students between the quality of teaching of the teachers and the interpersonal relation of the students. Another important aspect is the positive moderate correlation of 0,56 of the relation between teachers and students. Likewise, it is observed that the teaching quality is directly associated with the quality of the infrastructure, through a coefficient of 0,42 , and by the interrelation of the students, being its coefficient of correlation of 0,40 . The understanding of the concepts by the student is associated by means of the choice of the desired career, by presenting a correlation coefficient of 0,41 . The factors associated with the students' satisfaction with the career they study are particularly interesting. It was found that factors: Classes understanding (I14), Family support (E4), Teaching quality (E5), Teacher relation (E6), Student relation (E7), and the Infrastructure quality (E8), has a poor or weak linear correlation coefficient average of: 0,27, 0,24, 0,28, 0,40,0,27, and 0,36, respectively, see Figure 6. 
Figure 6. Correlated factors grade to Career satisfaction (E3).

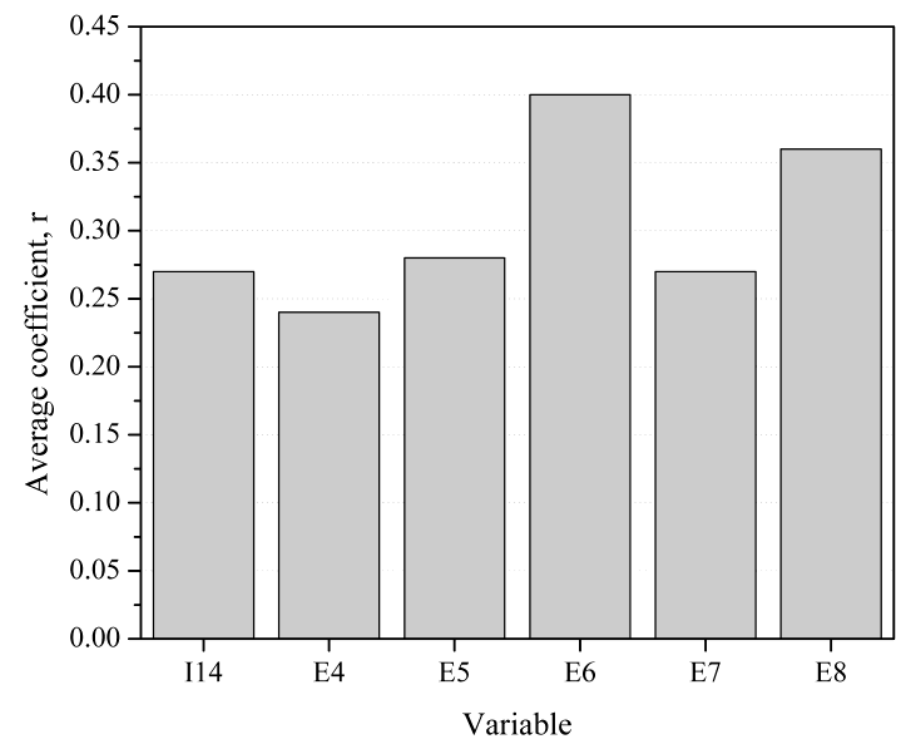

Source: own elaboration

On the other hand, the factors presenting a very weak linear correlation coefficient, ranges from $0<\mathrm{r} \leq$ 0,2, are: Age (I1), Family members (I2), Work time (I3), Monthly income (I4), Daily spending (I8), and Drug consumption (I12). All of these factors lack of any relation between the rests of them, by this reason these internal factors were discarded. 


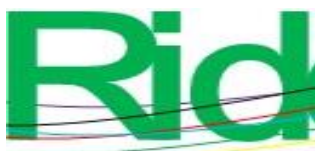

Revista Iberoamericana para la

Investigación y el Desarrollo Educativo

ISSN 2007 - 7467

Table 2. Pearson and Spearman linear correlation coefficient average

\begin{tabular}{|c|c|c|c|c|c|c|c|c|c|c|c|c|c|c|c|c|c|c|c|c|c|c|c|}
\hline Factor & $=$ & $\simeq$ & $\underline{m}$ & \pm & 느 & $\underline{\underline{ }}$ & $=$ & تี & $\underline{\infty}$ & 음 & พ & 을 & $\Xi$ & $\Xi$ & $\stackrel{m}{=}$ & พ̊ & 岀 & $\Xi$ & น & 요 & ثิ & 趈 & ํㅛ \\
\hline $\begin{array}{c}\text { Family } \\
\text { members }\end{array}$ & $\bar{\sigma}$ & & & & & & & & & & & & & & & & & & & & & & \\
\hline Work Time & $\frac{1}{\sigma}$ & $\frac{m}{\sigma}$ & & & & & & & & & & & & & & & & & & & & & \\
\hline $\begin{array}{l}\text { Monthly } \\
\text { income }\end{array}$ & 용 & $\begin{array}{l}\text { ్. } \\
\text { în }\end{array}$ & $\stackrel{8}{8}$ & & & & & & & & & & & & & & & & & & & & \\
\hline $\begin{array}{l}\text { Middle } \\
\text { school } \\
\text { average }\end{array}$ & $\underset{i}{E}$ & $\begin{array}{l}8 \\
0 \\
\\
\end{array}$ & $\begin{array}{l}8 \\
0 \\
\end{array}$ & $\frac{\nabla}{\circ}$ & & & & & & & & & & & & & & & & & & & \\
\hline $\begin{array}{l}\text { Failed at } \\
\text { middle } \\
\text { school }\end{array}$ & $\begin{array}{l}\text { ஜo } \\
\text { ó }\end{array}$ & $\frac{m}{i}$ & $\underset{i}{E}$ & $\begin{array}{l}\text { O̊ } \\
\text { o }\end{array}$ & $\stackrel{\infty}{\stackrel{\infty}{0}}$ & & & & & & & & & & & & & & & & & & \\
\hline $\begin{array}{l}\text { Failed at } \\
\text { high school }\end{array}$ & 8 & $\begin{array}{l}\text { ऽ } \\
\text { - }\end{array}$ & $\stackrel{m}{\sigma}$ & $\stackrel{m}{\sigma}$ & $\begin{array}{l}\text { mn } \\
\text { in }\end{array}$ & $\begin{array}{l}\text { N } \\
\text { o }\end{array}$ & & & & & & & & & & & & & & & & & \\
\hline $\begin{array}{c}\text { Transport } \\
\text { time }\end{array}$ & $\bar{\delta}$ & $\stackrel{m}{\sigma}$ & $\underset{\sigma}{E}$ & $\begin{array}{l}\stackrel{2}{2} \\
\text { ị }\end{array}$ & $\begin{array}{l}\text { o. } \\
\text { i. }\end{array}$ & 8 & 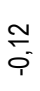 & & & & & & & & & & & & & & & & \\
\hline $\begin{array}{c}\text { Daily } \\
\text { spending }\end{array}$ & : & $\frac{0}{i}$ & $\stackrel{\infty}{\circ}$ & $\stackrel{2}{2}$ & $\begin{array}{l}20 \\
0 \\
\end{array}$ & $\begin{array}{l}\text { ¿ } \\
\text { i }\end{array}$ & ণ & m̃ & & & & & & & & & & & & & & & \\
\hline $\begin{array}{c}\text { Extra study } \\
\text { time }\end{array}$ & $\frac{0}{0}$ & Oֶ. & $\frac{10}{9}$ & $\begin{array}{l}8 \\
\end{array}$ & $\stackrel{\bar{\sigma}}{\sigma}$ & $\begin{array}{l}\text { o } \\
\text { o }\end{array}$ & $\begin{array}{l}\text { లి } \\
\text { ô }\end{array}$ & $\begin{array}{l}\mathscr{8} \\
0\end{array}$ & $\stackrel{2}{2}$ & & & & & & & & & & & & & & \\
\hline $\begin{array}{c}\text { Distraction } \\
\text { time }\end{array}$ & $\stackrel{\infty}{\infty}$ & $\begin{array}{l}8 \\
0 \\
\\
\end{array}$ & 응 & $\stackrel{\infty}{\circ}$ & $\frac{0}{0}$ & $\begin{array}{l}\text { a } \\
\text { o }\end{array}$ & $\frac{}{\circ}$ & $\frac{0}{\circ}$ & $\begin{array}{l}\text { 으 } \\
\text { i }\end{array}$ & $\stackrel{L}{2}$ & & & & & & & & & & & & & \\
\hline $\begin{array}{c}\text { Device } \\
\text { usage time }\end{array}$ & $\stackrel{\simeq}{\circ}$ & $\frac{\infty}{\phi^{\prime}}$ & $\stackrel{2}{2}$ & p. & O. & $\bar{\sigma}$ & స్ & $\begin{array}{l}\stackrel{2}{2} \\
\stackrel{1}{1}\end{array}$ & $\frac{N}{i s}$ & O্. & ¿ & & & & & & & & & & & & \\
\hline $\begin{array}{l}\text { Time use } \\
\text { of device }\end{array}$ & ర్ & ס & $\frac{\nabla}{\sigma}$ & 品 & $\frac{6}{5}$ & $\bar{\delta}$ & $\begin{array}{l}8 \\
\text { : } \\
\end{array}$ & ర్ & $\bar{\delta}$ & $\stackrel{\simeq}{0}$ & స̃ & ठ̊ & & & & & & & & & & & \\
\hline $\begin{array}{c}\text { Drug } \\
\text { consump- } \\
\text { tion }\end{array}$ & 응 & o. & $\frac{\text { ㅁ }}{\circ}$ & $\overline{0}$ & 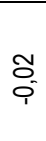 & $\begin{array}{l}\text { న్ } \\
\text { în }\end{array}$ & $\stackrel{2}{2}$ & $\frac{10}{i}$ & $E_{i}$ & $\frac{0}{i-i}$ & $\stackrel{\infty}{\sigma}$ & $\tilde{\sigma}$ & $\stackrel{8}{8}$ & & & & & & & & & & \\
\hline $\begin{array}{c}\text { Desired } \\
\text { career }\end{array}$ & 范 & $\bar{\delta}$ & ס̊ & $\bar{\sigma}$ & $\stackrel{\infty}{\circ}$ & $\begin{array}{l}\text { oo } \\
\text { o }\end{array}$ & $\begin{array}{l}\infty \\
0 \\
\end{array}$ & O̊ & $\frac{0}{i}$ & 능 & $\bar{\sigma}$ & Oֶ. & $\underset{i}{\bar{i}}$ & $\delta_{0}$ & & & & & & & & & \\
\hline $\begin{array}{c}\text { Career } \\
\text { satisfaction }\end{array}$ & 응 & $\begin{array}{l}\text { to } \\
\text { i }\end{array}$ & $\stackrel{2}{\circ}$ & స̃ & $\stackrel{\oplus}{\circ}$ & $\begin{array}{l}\text { Oे } \\
0\end{array}$ & \begin{tabular}{l} 
o \\
\hdashline \\
1
\end{tabular} & $\frac{\nabla}{i}$ & $\frac{0}{0}$ & $\stackrel{\infty}{\circ}$ & $\begin{array}{l}\text { ö } \\
\\
\end{array}$ & 뇽 & $\frac{\nabla}{i !}$ & $\stackrel{\simeq}{\circ}$ & in & & & & & & & & \\
\hline $\begin{array}{l}\text { Family } \\
\text { support }\end{array}$ & $\frac{0}{0}$ & $\begin{array}{l}\text { ¿̊ } \\
\text { o. }\end{array}$ & $\begin{array}{l}\text { N } \\
0 \\
\end{array}$ & $\frac{}{0}$ & : & $\frac{\nabla}{\sigma}$ & $\begin{array}{l}\text { ్ } \\
\text { in }\end{array}$ & $\frac{m}{i s}$ & $\begin{array}{l}\text { U } \\
0\end{array}$ & $\stackrel{\stackrel{2}{0}}{0}$ & $\begin{array}{l}\overline{0} \\
\\
1\end{array}$ & $\begin{array}{l}8 \\
0 \\
\\
\end{array}$ & $\begin{array}{l}\widetilde{1} \\
\text { o. }\end{array}$ & $\stackrel{2}{\circ}$ & So & $\underset{\Xi}{\stackrel{J}{\sigma}}$ & & & & & & & \\
\hline $\begin{array}{l}\text { Classes } \\
\text { under- } \\
\text { standing }\end{array}$ & S. & $\frac{0}{i}$ & $\delta_{0}$ & $\begin{array}{l}8 \\
0 \\
\end{array}$ & O্ & 응 & $\begin{array}{l}\text { స̃ } \\
\text { is }\end{array}$ & $\stackrel{0}{0}$ & So & 응 & ס̊ & \begin{tabular}{l} 
o \\
\hdashline \\
1
\end{tabular} & $\begin{array}{l}8 \\
0 \\
\end{array}$ & $\begin{array}{l}\text { to } \\
\text { i }\end{array}$ & 宓 & స̃ & $\frac{m}{\sigma}$ & & & & & & \\
\hline $\begin{array}{l}\text { Teaching } \\
\text { quality }\end{array}$ & $\begin{array}{l}\infty \\
0 \\
1\end{array}$ & O. & $\begin{array}{l}\text { O̊ } \\
0 \\
\end{array}$ & $\frac{}{0}$ & Oֶ. & $\begin{array}{l}\bar{\sigma} \\
\bar{q}\end{array}$ & $\frac{\nabla}{\sigma}$ & $\bar{c}$ & $\stackrel{8}{\circ}$ & $\begin{array}{l}\bar{\alpha} \\
\\
\end{array}$ & $\frac{m}{i}$ & $\frac{0}{i=-}$ & \begin{tabular}{l}
$\stackrel{2}{2}$ \\
\hdashline \\
\hdashline
\end{tabular} & $\begin{array}{l}\text { ô } \\
\text { ó }\end{array}$ & $\frac{0}{0}$ & 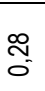 & $\hat{n}$ & $\begin{array}{l}8 \\
\square \\
\end{array}$ & & & & & \\
\hline
\end{tabular}




\begin{tabular}{|c|c|c|c|c|c|c|c|c|c|c|c|c|c|c|c|c|c|c|c|c|c|c|c|}
\hline $\begin{array}{l}\text { Teacher } \\
\text { relation }\end{array}$ & $\cong$ & 8 & $E_{i}$ & $\begin{array}{l}\text { ơ } \\
\text { o. }\end{array}$ & $E$ & 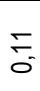 & 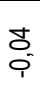 & $\begin{array}{l}\infty \\
0 \\
\end{array}$ & $\begin{array}{l}\text { ָ̊ } \\
\text { ô }\end{array}$ & $\begin{array}{l}8 \\
0 \\
\end{array}$ & ס̊ & $\begin{array}{l}8 \\
0 \\
\end{array}$ & 용 & : & প্ল & 웅 & 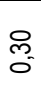 & $\frac{\text { 응 }}{-1}$ & 吕 & & & & \\
\hline $\begin{array}{l}\text { Students } \\
\text { relation }\end{array}$ & חొ & $\begin{array}{l}\text { Oे } \\
0_{0}^{\prime}\end{array}$ & 용 & $\frac{\infty}{\sigma}$ & 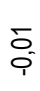 & $\frac{m}{\sigma}$ & స్ & $\frac{0}{0}$ & $\frac{\nabla}{\square}$ & $\Sigma_{i}$ & $\stackrel{\infty}{\circ}$ & ర్ & $\frac{0}{\text { - }}$ & $\stackrel{2}{2}$ & $\underset{\sigma}{E}$ & స్ & ్ָ & $\begin{array}{l}\text { ơ } \\
\text { o- }\end{array}$ & ơ & $\begin{array}{l}0 \\
0 \\
0 \\
0\end{array}$ & & & \\
\hline $\begin{array}{c}\text { Infrastruc- } \\
\text { ture } \\
\text { quality }\end{array}$ & $\begin{array}{l}\text { O̊ } \\
\text { i. }\end{array}$ & $\begin{array}{l}\bar{\delta} \\
\bar{\phi}\end{array}$ & ָ̊ & $\begin{array}{l}\text { ơ } \\
\text { o }\end{array}$ & $\stackrel{m}{5}$ & $\frac{\nabla}{\sigma}$ & ర్ & $\begin{array}{l}\widetilde{N} \\
\text { ô }\end{array}$ & \begin{tabular}{l}
$\infty 0$ \\
\hdashline \\
\end{tabular} & $\stackrel{F}{i}$ & ס̊ & $\frac{m}{i}$ & $\begin{array}{l}20 \\
0 \\
\end{array}$ & ָั & $\stackrel{\infty}{\sigma}$ & ֻׁ & $\frac{0}{0}$ & $\underset{\widetilde{\sigma}}{\check{\sigma}}$ & $\stackrel{\text { Y }}{0}$ & $\stackrel{m}{\overbrace{0}^{\prime}}$ & 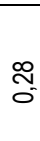 & & \\
\hline $\begin{array}{l}\text { Family } \\
\text { troubles }\end{array}$ & 웅 & 응 & $\stackrel{\infty}{\circ}$ & $\frac{m}{i}$ & 용 & $\frac{\nabla}{\sigma_{1}}$ & $\frac{\nabla}{\sigma}$ & $\stackrel{\cong}{\sigma}$ & $\frac{1}{1}$ & $\begin{array}{l}\infty \\
0 \\
0 \\
\end{array}$ & $\bar{\sigma}$ & 욤 & $\bar{\sigma}$ & $\begin{array}{l}\infty \\
0\end{array}$ & $\bar{\delta}_{0}$ & ${ }_{0}^{\circ}$ & $\begin{array}{c}\bar{m} \\
0 \\
1\end{array}$ & 용 & $\frac{\nabla}{i}$ & $\begin{array}{l}\text { o. } \\
\text { - }\end{array}$ & $\stackrel{\infty}{\leftarrow}$ & ס̊ & \\
\hline $\begin{array}{c}\text { Health } \\
\text { condition }\end{array}$ & ס & 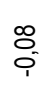 & $\frac{\text { g) }}{\sigma_{i}}$ & : & \&: & 용 & $\begin{array}{l}\text { to } \\
\text { i }\end{array}$ & $\begin{array}{l}\text { ¿্ } \\
\\
\end{array}$ & '용 & O̊ & \begin{tabular}{l}
$\infty$ \\
\hdashline \\
1
\end{tabular} & 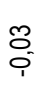 & $\frac{m}{i}$ & ָั & ণ্ & 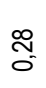 & ơ & $\stackrel{\cong}{\check{\sigma}}$ & $\stackrel{\sim}{\tilde{\sigma}}$ & 守 & f́t & लु & প্ণি \\
\hline
\end{tabular}

Source: own elaboration

\section{Conclusions}

This research has found that some factors determine or influence to failing courses at high school, are essentially internal factors which are directly associated with the student. These internal factors are Middle school average, Failed at middle school, Extra study time, Use of devices, and Classes understanding. The historical background measured by failed courses and its average in final notes of middle school has an interesting inverse correlation to success in high school. This could be due to an underestimation of the high school level by outstanding students. The external factor, Student relation, is the unique external factor that seems to positively influence student's performance. A good student's interrelation enhances the possibility to complete courses. Although previous works conclude that there is not a correlation between Extra study time and failure in high school, in this research the opposite was observed: a weak but negative correlation between these two internal factors. On the other hand, the Use of electronic devices and access to facilities negatively influence the accomplishment of courses: while less quantity and Devices usage time, more success in high school are expected. Even though the "logical" self-efficacy factor Classes understanding also has an inverse relation to Failure in courses, likewise, the selfefficacy is determined by the correct selection of the career. A preliminary conclusion about $\mathrm{Ca}$ reer satisfaction is observed, a predominant dependence on external factors, including Family support, Teaching quality, Teacher and Students' relation, and Infrastructure's quality; all of them have a direct influence on it. Only an internal factor appears to be directly related to Career satisfaction, i.e., Classes understanding. The professor's Teaching quality seems to be influenced by the external factors Infrastructure quality and the Student's relation, which also is associated with Teacher's relation. Regarding the none-correlated factors, is observed that only internal 

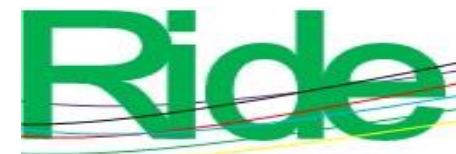

Revista Iberoamericana para la Investigación y el Desarrollo Educativo

ISSN 2007 - 7467

factors lack of any relation respect to the rest, these are Age, Family members, Work time, Monthly income, Daily spending, and Drug consumption. In order to improve correlation grade, it is necessary to increase the sample size and to expand to other career topics. It is imperative to create an instrument to evaluate the proposed -and hypothetical- causes of correlated a pair of factors associated with "Failed at high school" and "Career satisfaction". This study is proposed to make real suggestions to prevent school drop-out, as well as to diminish the non-accepted social effects that this complex social research may cause in the future. And as additional future work, we are aiming to expand the test in other specialization areas, by using a smartphone App, to facilitate the data capture and the mathematical analysis.

\section{Acknowledgments}

The authors want to thank Professor María Belén Magadán Hernández for their support in grammar and spell correction of this article. Special thanks to engineer Grecia Monserrat Ibañez Victoria for her support in conducting the surveys. Finally, it is important to acknowledge to the Universidad Politécnica del Estado de Guerrero for financial support. 


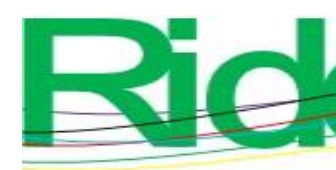

Revista Iberoamericana para la Investigación y el Desarrollo Educativo ISSN $2007-7467$

\section{References}

Alanís, N. J., Casarrubias, D. B., Cantú, R. A., \& Lavín, D. J. (2017). Correlación y regresión lineal de variables climatológicas para el diseño de ecotecnologías y arquitectura bioclimática. Revista de Arquitectura y Diseño, 1(2) 1-12.

Beck, H. P., \& Davidson, W. D. (2001). ESTABLISHING AN EARLY WARNING SYSTEM: Predicting Low Grades on Collegue Students from Survey of Academic Orientations Scores. Research in Higher Education, 42(6), 709-723.

Blanz, M. (2013). How do study satisfaction and academic performance interrelate? An investigation with students of Social Work programs. European Journal of Social Work, 17(2), 281-292.

Devore, J. L. (2008). Probabilidad y estadística para ingeniería y ciencias. México D.F.: Cengage Learning.

Fenning, B. E., \& May, L. N. (2013). "Where there is a will, there is an A": examining the roles of self-efficacy and self-concept in college students current educational attainment and career planning. Soc Physcol Educ, 16(4), 635-650.

Finch, J., \& Taylor, I. (2013). Failure to fail? Practice educators' emotional experiences of assessing failing social work students. Social Work Education, 32(2), 244-258.

Herrera, C. A. (2016). Diagnóstico del rendimiento académio de estudiantes de una escuela de educación superior en México. Revista Complutense de Educación, 1369 - 1388.

Komarraju, M., Ramsey, A., \& Rinella, V. (2012). Cognitive and non-cognitive predictors of college readiness and performance: Role of academic discipline. Learning and Individual Differences, 24, 103-109.

Martínez, B. C. (2008). Probabilidad y estadística para ingeniería y ciencias. Bogotá: Cengage Learning.

Nonis, S. A., \& Hudson, G. I. (2010). Academic Performance of College Students: Influence of Time Spent Studying and Working. Journal of Education for Business, 81(13), 151-159.

Park, E. 1., \& Choi, B. K. (2014). Transformation of classrooms spaces: traditional versus active learning clasrooms in colleges. High Education, 68(5), 749-771.

Pearson, K. (1920). Notes on the history of correlation. Biometrika, 25-45.

Roman, M. D. (2013). Students' Failure in Academic Environment. Procedia - Social and Behavioral Sciences, 114, 170-177.

Spearman, C. (1904). The proof and measurement of association between two things. Am. J.

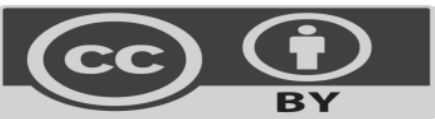




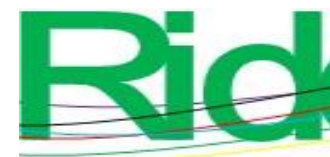

Psychol., 15, 72-101.

Spiegel, M. R., \& Stephens, L. J. (2009). Estadística. México D.F.: Mc Graw Hill.

Torres, S. M. (2014). The Relation Between Latino Student's Learning Styles and Their Academic Performance. Community College Journal of Research, 38(4), 357-369.

Zou, K. H., Tuncali, K., \& Silverman, S. G. (2003). Correlation and simple linear regression. Radiology, 227(1), 617-628. 


\begin{tabular}{|c|c|}
\hline Rol de Contribución & Autor (es) \\
\hline Conceptualización & José Andrés Alanís Navarro \\
\hline Metodología & José Andrés Alanís Navarro \\
\hline Software & $\begin{array}{l}\text { José Andrés Alanís Navarro «igual», } \\
\text { Reynaldo Alanís Cantú «igual» }\end{array}$ \\
\hline Validación & $\begin{array}{c}\text { José Andrés Alanís Navarro «igual», } \\
\text { Agustin Barón «igual» }\end{array}$ \\
\hline Análisis Formal & $\begin{array}{c}\text { José Andrés Alanís Navarro «igual», } \\
\text { Reynaldo Alanís Cantú «igual» }\end{array}$ \\
\hline Investigación & $\begin{array}{l}\text { José Andrés Alanís Navarro «igual», } \\
\text { Reynaldo Alanís Cantú «igual» }\end{array}$ \\
\hline Recursos & $\begin{array}{c}\text { José Andrés Alanís Navarro«principal», } \\
\text { Reynaldo Alanís Cantú «apoyo», } \\
\text { Agustin Barón «apoyo» }\end{array}$ \\
\hline Curación de datos & $\begin{array}{c}\text { José Andrés Alanís Navarro «principal», } \\
\text { Reynaldo Alanís Cantú «apoyo» }\end{array}$ \\
\hline $\begin{array}{l}\text { Escritura - Preparación del } \\
\text { borrador original }\end{array}$ & $\begin{array}{c}\text { José Andrés Alanís Navarro «principal», } \\
\text { Reynaldo Alanís Cantú «apoyo», } \\
\text { Agustin Barón «apoyo» }\end{array}$ \\
\hline $\begin{array}{c}\text { Escritura - Revisión y edi- } \\
\text { ción }\end{array}$ & $\begin{array}{c}\text { José Andrés Alanís Navarro «principal», } \\
\text { Reynaldo Alanís Cantú «apoyo», } \\
\text { Agustin Barón «apoyo» }\end{array}$ \\
\hline Visualización & $\begin{array}{c}\text { José Andrés Alanís Navarro «principal», } \\
\text { Reynaldo Alanís Cantú «apoyo» }\end{array}$ \\
\hline Supervisión & José Andrés Alanís Navarro \\
\hline $\begin{array}{l}\text { Administración de Proyec- } \\
\text { tos }\end{array}$ & José Andrés Alanís Navarro \\
\hline Adquisición de fondos & José Andrés Alanís Navarro \\
\hline
\end{tabular}




\section{Appendix A}

Quiz

\section{A) General data}

Age: ; Number of members in your current home

How many hours do you work at week? ; Family monthly income

\section{B) Academic History}

High school average: ; Did you fail any subject in the high school? (Yes)(No);

Subjects failed to date in the university:

\section{C) Quiz}

1. - How many hours or minutes do you invest daily to arrive to college?

2. - How much money do you invest daily in transport and food? $\$$

3. - How many hours a day extra to the class, do you dedicate to studying?

4. - How many hours a week do you share with your partner or friends?

5. - Which of the following services or devices do you have in your home?

(Pay TV) (Internet) (Phone) (Cellphone) (Tablet) (Laptop) (Videogames) (Others)

6. - How many daily hours do you dedicate to the use to those devices or services?

7. - Do you frequently consume some of these substances?

(Cigar) (Alcohol) (Marihuana) (Cocaine) (Others)

\section{Answer the following questions on a scale of 1 to 10}

8. - How sure are you to have chosen the right career? 1 means nothing sure; 10 means completely sure:

9. - Satisfaction with your career: 1 means nothing satisfied; 10 means totally satisfied:

10. - How much family support do you receive to complete your career? 1 means nothing and 10 means unconditionally:

11. - How difficult is to understand the content of the subjects? 1 means very difficult; 10 means very easy:

12. - How would you rate the teaching quality of your teachers? 1 means bad; 10 means excellent:

13. - How will you evaluate the relation with your teacher? 1 means bad; 10 means excellent:

14. - How would you define the relation between the students? 1 means bad; 10 means excellent:

15. - Quality of the university infrastructure: 1 means bad; 10 means excellent:

16. - Do you have family problems? 1 I never have family problems; 10 I always have family problems:

17. - How do you consider your current health status? 1 with problems: 10 perfect health 


\section{Appendix B}

Table 3. Nomenclature

\begin{tabular}{|c|c|}
\hline Symbol & Description \\
\hline$e$ & Error \\
\hline$k$ & Kurtosis \\
\hline$n$ & Sample size \\
\hline$N$ & Population size \\
\hline$r$ & Linear correlation average coefficient \\
\hline$r_{p}$ & Pearson linear correlation coefficient \\
\hline$r_{s}$ & Spearman linear correlation coefficient \\
\hline $\mathrm{S}$ & Standard deviation \\
\hline $\mathrm{s}^{2}$ & Variance \\
\hline$s k$ & Skewness \\
\hline$C V$ & Coefficient of variation \\
\hline $\bar{x}$ & Sample mean, average \\
\hline$\tilde{x}$ & Sample median \\
\hline$\hat{x}$ & Sample mode \\
\hline $\mathrm{X}_{\min }$ & Minimum value \\
\hline $\mathbf{X}_{\max }$ & Maximum value \\
\hline$Z$ & Hope level \\
\hline
\end{tabular}

Source: own elaboration 


\section{Appendix C}

Table 4. Mnemonic of internal and external factors

\begin{tabular}{|c|c|}
\hline Factor & Symbol \\
\hline Age & $\mathrm{I} 1 *$ \\
\hline Family members & $\mathrm{I} 2$ \\
\hline Work time & $\mathrm{I} 3$ \\
\hline Monthly income & $\mathrm{I} 4$ \\
\hline Middle school average & I5 \\
\hline Failed at middle school & I6 \\
\hline Failed at high school & I7 \\
\hline Transportation time & $\mathrm{E} 1 *$ \\
\hline Daily spending & I8 \\
\hline Extra study time & I9 \\
\hline Distraction time & $\mathrm{E} 2$ \\
\hline Use of devices & I10 \\
\hline Device usage time & I11 \\
\hline Drug consumption & I12 \\
\hline Desired career & I13 \\
\hline Career satisfaction & E3 \\
\hline Family support & E4 \\
\hline Classes understanding & I14 \\
\hline Teaching quality & E5 \\
\hline Teacher relation & E6 \\
\hline Students relation & E7 \\
\hline Infrastructure quality & $\mathrm{E} 8$ \\
\hline Family troubles & E9 \\
\hline Health condition & $\mathrm{I} 15$ \\
\hline
\end{tabular}

*I: Internal, E: External.

Source: own elaboration 